\title{
Antineoplastic Effect of Procyanidin-rich Extract of Lafoensia Pacari in Lung Carcinoma Cells
}

\author{
Yonara de Gouveia Cordeiro ${ }^{1}$
}

https://orcid.org/0000-0001-6145-3642

Arina Lázaro Rochetti ${ }^{1}$

https://orcid.org/0000-0002-1225-1953

Vinicius Castro Souza ${ }^{2}$

https://orcid.org/0000-0002-3733-7892

Edson Roberto da Silva ${ }^{3}$

https://orcid.org/0000-0002-6246-4404

Antônio Márcio Scatolini ${ }^{4}$

https://orcid.org/0000-0002-8153-6469

Maria Inés Genovese ${ }^{5}$

https://orcid.org/0000-0002-1322-3129

George Shigueki Yasui ${ }^{6}$

https://orcid.org/0000-0002-6105-8308

Heidge Fukumasu ${ }^{1 *}$

https://orcid.org/0000-0002-3265-5090

${ }^{1}$ University of São Paulo, Faculty of Animal Science and Food Engineering, Department of Veterinary
Medicine, Laboratory of Comparative and Translational Oncology, Pirassununga, São Paulo, Brazil; ${ }^{2}$
University of São Paulo, "Escola Superior de Agricultura Luiz de Queiroz", Department of Biological
Sciences, Piracicaba, São Paulo, Brazil; ${ }^{3}$ University of São Paulo, Faculty of Animal Science and
Food Engineering, Department of Veterinary Medicine, Pirassununga, São Paulo, Brazil; ${ }^{4}$ University
of São Paulo, Faculty of Animal Science and Food Engineering, Department of Basic Sciences,
Pirassununga, São Paulo, Brazil; ${ }^{5}$ University of São Paulo, Faculty of Pharmaceutical Science,
Department of Food and Experimental Nutrition, São Paulo, São Paulo, Brazil; 'National Center for
Research and Conservation of Continental Species, Pirassununga, São Paulo, Brazil.

Received: 2016.07.27; Accepted: 2017.10.23.

* Correspondence: fukumasu@usp.br; Tel.: +55-19-35656864 


\section{HIGHLIGHTS}

- L. pacari has ethnopharmacological indication as anti-ulcerogenic and anti-inflammatory.

- L. pacari extract is cytotoxic against lung cancer cells.

- L. pacari extract is rich in procyanidins, well-known for antioxidant effects.

Abstract: Lafoensia pacari A. St. Hill has been used in traditional medicine as an anti-ulcerogenic and anti-inflammatory. Although there is an ethnopharmacological indication for cancer treatment, only a few studies have demonstrated its possible anticancer activity. Thus, the aims of this study were: (1) to evaluate the antineoplastic effect of $L$. pacari ethanolic extract (LPE) in lung carcinoma cells, (2) to determine the mode of action of LPE and (3) to identify the substances present in LPE. Human and murine lung cancer cell lines were grown in vitro and treated with different concentrations of LPE. Cell cycle and caspase-3 activity assays were performed in order to verify the mode of action. LC-ESI-MS screening was performed to detect the compounds present in LPE. LPE showed a dose-dependent cytotoxic effect, where neoplastic cells were more sensitive than non-neoplastic. The LPE induced sub-G1 cell cycle arrest in cancer cells suggesting cell death, which was confirmed as apoptosis by the activation of caspase-3. The LC-ESI-MS analysis indicated a high level of procyanidins, which could be responsible for the antineoplastic effect of LPE. Thus, we concluded that a Lafoensia pacari extract, rich in procyanidins, is cytotoxic against lung cancer cells through activation of caspase-3-dependent apoptosis.

Keywords: antineoplastic effect, cell cytotoxicity, medicinal plants, procyanidins

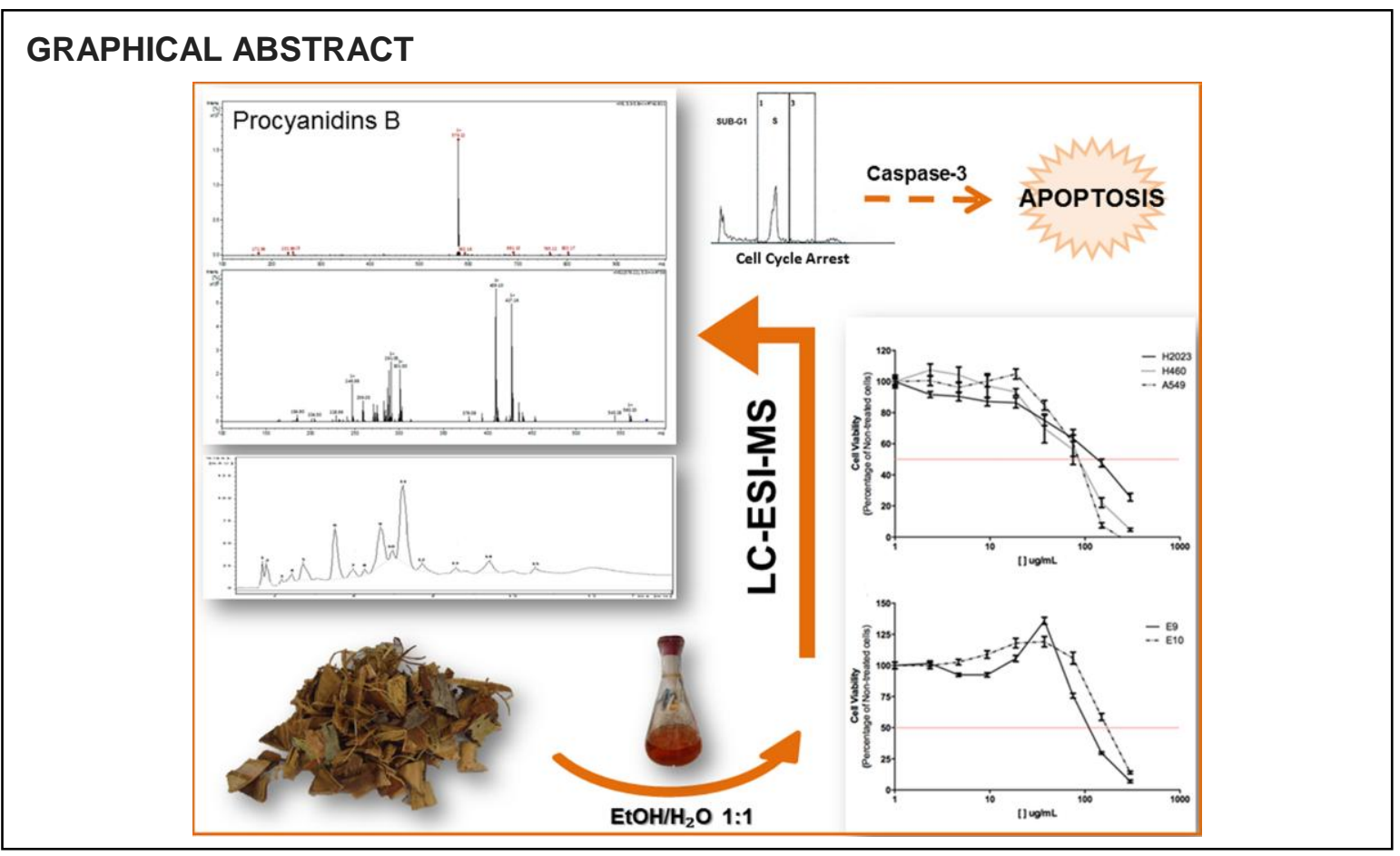




\section{INTRODUCTION}

Plants have been used worldwide for the therapy and prevention of several diseases in humans and animals [1,2], however some of these plants only became part of the allopathic and homeopathic pharmacopoeias at the beginning of the 20th century [3]. Ethnopharmacology has led to an extraordinary advancement in medicine, leading to the discovery of several substances that are now commonly used against cancer, such as Paclitaxel and Topotecan [4,5]. To date, several plant species have shown interesting preventive and/or therapeutic effects against cancer, providing many options for the discovery and development of new molecules targeting the diverse alterations found in cancers [6-8]. Most of the bioactive molecules responsible for the effects observed in medicinal plants are secondary metabolites, substances that do not appear to participate directly in plant growth and development [9]. When consumed by living organisms, these metabolites, named phytochemicals, can modulate the metabolism of cells and protect them against carcinogenic substances [10], as well as targeting cancer cells and inducing cell death.

The Lythracea family is native to South America and includes approximately 500 species. Lafoensia pacari A. St. Hill can be found specifically in the Brazilian Cerrado [11]. Known popularly in Brazil as "Dedaleira" or "Mangava-brava", L. pacari has been used in traditional medicine as an anti-ulcerogenic and anti-inflammatory [12], and different preparations are used depending on the disease. Maceration of the inner bark followed by oral ingestion is the most common way to treat gastric ulcers and weight loss and can be used in this form as an antipyretic. It can also be used topically for dermatological conditions [13]. When used to treat patients with cancer, people usually drink the extract of the bark after decoction, by adding some salt and a small amount of ethanol [12]. The hydroalcoholic extract of $L$. pacari stem bark contains tannins, steroids, triterpenes and saponins [12]. Thus, our objective was to evaluate the possible antineoplastic effect of $L$. pacari hydroethanolic extract (LPE) in lung cancer cell lines, since those cancers have the highest rates of incidence and mortality worldwide [14].

\section{MATERIAL AND METHODS}

\section{Extract preparation.}

Samples of bark and stem bark were collected in Piracicaba, state of Sao Paulo - Brazil, from standing trees located inside the campus of University of São Paulo (ESALQ-USP). Botanical identification was performed and the Voucher specimen (identification ESA 129860) was deposited in the ESA (Herbarium from ESALQ-USP). The plant name was properly checked in www.theplantlist.org (accessed in April 6th, 2016). The dried and grounded material was extracted with $50 \%$ ethanol during 48 hours. The extract was filtered and ethanol was removed by rota-evaporation under reduced pressure resulting in Hydroethanolic Extract (LPE). LPE was frozen at $-50^{\circ} \mathrm{C}$ and lyophilized resulting in a dried extract.

\section{Cell lines and cytotoxic analysis.}

For the assessment of cytotoxicity of LPE, different cell lines (purchased from ATCC®, Virginia, USA) were grown in vitro (Table 1). Cells were cultured in triplicates in 96-well plates for $24 \mathrm{~h}$ in a humidified incubator at $37^{\circ} \mathrm{C}$ and $7 \% \mathrm{CO} 2$ in RPMI 1640 (lung human cells), CMRL 1066 (murine cells) and DMEM (human fibroblast) media, supplemented with $10 \%$ fetal bovine serum (InvitrogenTM, Carlsbad, CA), 2\% GlutaMAX (InvitrogenTM, Carlsbad, CA) and 1\% penicillin/streptomycin (InvitrogenTM, Carlsbad, CA). LPE was diluted in the medium described above and exposed with concentrations ranging from 3.12 to $400.00 \mu \mathrm{g} / \mathrm{mL}$ for $72 \mathrm{~h}$. Then, cell viability was assessed using MTT (3 (4,5-dimethylthiazol-2yl) -2,5-diphenyl bromide tetrazolium, Sigma Aldrich, St. Louis, MO, USA) assay, widely used to determine the viability of cultured cells. 
Table 1. Cell lines used to perform L. pacari cytotoxic assay.

\begin{tabular}{ccc}
\hline Cell line & Species & Origin tissue \\
\hline A549 & Human & NSCLC, adenocarcinoma \\
H2023 & Human & NSCLC, adenocarcinoma \\
H460 & Human & NSCLC, large cell lung carcinoma \\
BJ & Human & Foreskin fibroblast, normal \\
E9 & Mouse & Tumorigenic alveolar type II pneumocytes \\
E10 & Mouse & Immortalized alveolar type II pneumocytes \\
\hline
\end{tabular}

NSCLC: non-small cell lung cancer.

\section{Cell cycle analysis.}

Briefly, $2 \times 10^{4} \mathrm{H} 460$ cells were grown as described for $24 \mathrm{~h}$. The culture medium was discarded and cells were treated for $72 \mathrm{~h}$ with $100 \mu \mathrm{g} / \mathrm{mL}$ of LPE. Then, cells were detached using $0.05 \%$ trypsin/EDTA solution. Non-treated cells were used as controls. Staining was achieved using a DAPI (4',6-diamidino-2-phenylindole) solution, Sigma Aldrich, St. Louis, MO, USA) dissolved in calcium and magnesium-free Dulbecco's PBS (Sigma Aldrich, St. Louis, MO, USA) at $1 \mu \mathrm{g} / \mathrm{mL}$. Flow cytometry analysis was then performed (Partec CyFlow® Ploidy Analyzer, Partec, GMBh, Germany). The experiment was performed in triplicates. Most LPE sensitive cell line was used to cell cycle and cell death analyses.

\section{Cell death analysis.}

Again, $2 \times 10^{4} \mathrm{H} 460$ cells were grown as described for $24 \mathrm{~h}$. The culture medium was discarded and cells were treated for $72 \mathrm{~h}$ with $100 \mu \mathrm{g} / \mathrm{mL}$ of LPE. Then, cells were detached, and cleaved caspase-3 activity was analyzed by the Caspase-3/7 dependent staining of DNA NucViewTM 488 Caspase-3 Detection in Living Cells (Biotium, CA, USA), according to the manufacturer's recommendations. Positive and negative cells were counted using Image J software ( $\mathrm{NIH}$, Bethesda, Maryland, USA).

\section{Phytochemical characterization.}

Total Tannins Content. Total tannins from powdered bark, inner bark and ethanolic extract were determined according to the method of Hagerman and Butler, based on the precipitation using bovine serum albumin (BSA, Sigma Chemical Co., St. Louis, USA) [15]. Briefly, powdered extracts were dissolved and adequately diluted in $70 \%$ aqueous methanol and an aliquot $(1 \mathrm{~mL})$ was mixed with $2 \mathrm{~mL}$ of $\mathrm{BSA}(1 \mathrm{mg} / \mathrm{mL})$ and incubated at room temperature for $15 \mathrm{~min}$. After centrifugation at $5000 \mathrm{~g}$ for $10 \mathrm{~min}$, the supernatant was discarded, and the pellet was dissolved in $4 \mathrm{~mL}$ of SDS solution. One milliliter of the ferric chloride reagent was added, and after 20 min the absorbance at $510 \mathrm{~nm}$ was read on an Ultrospec 2000 (Amersham Biosciences, Cambridge, UK). Results were given in g of tannic acid per $100 \mathrm{~g}$ of powdered extract. Analysis by liquid chromatography-electrospray ionization-tandem mass spectrometry (LC-ESI-MS). The analysis of LPE was performed by LC-ESI-MS using a column Phenomenex Gemini C-18 in a Shimadzu HPLC system equipped with LC-20AD pump, a SIL 20AC autosampler and a SPD-20A detector. The sample was eluted with a linear gradient $10-30 \%$ of acetonitrile:water using phase A solvent $(0.1 \%$ acetic acid $/ \mathrm{H} 2 \mathrm{O})$ and acetonitrile as solvent in phase $\mathrm{B}$. The analysis was performed under a flow rate at $1.0 \mathrm{~mL} / \mathrm{min}$ detection at $280 \mathrm{~nm}$. Mass spectra were obtained with Amazon Speed ETD ion trap spectrometer (Bruker-Daltonics, MA, USA), with the electrospray operating in positive ion mode at flow rate of $9 \mathrm{~L} / \mathrm{min}$, drying gas at $300^{\circ} \mathrm{C}$ and under pressure of 40 psi. The capillary voltage was set at $4500 \mathrm{~V}$. 


\section{Statistical analysis.}

All data were presented as mean and standard deviation. Statistical analysis of cell cycle arrest and caspase-3 activity was assessed by unpaired t-test, between control and treated cells. All data, including regression curves and $\mathrm{IC}_{50}$ values, were analyzed in Prism 5.0 (GraphPad Software, USA).

\section{RESULTS}

First, we evaluated the effects of LPE on cell viability of three different human lung cancer cell lines and used normal fibroblast as the control. After $72 \mathrm{~h}$ of exposure, LPE induced a concentration-dependent cytotoxic effect in all cancer cell lines, demonstrating that non-small cell lung carcinoma cell lines are susceptible to the effect promoted by LPE bioactive components (Fig. 1). Among the three cell lines, the $\mathrm{H} 460$ cell line was the most sensitive to the cytotoxic effect of LPE (Table 2).
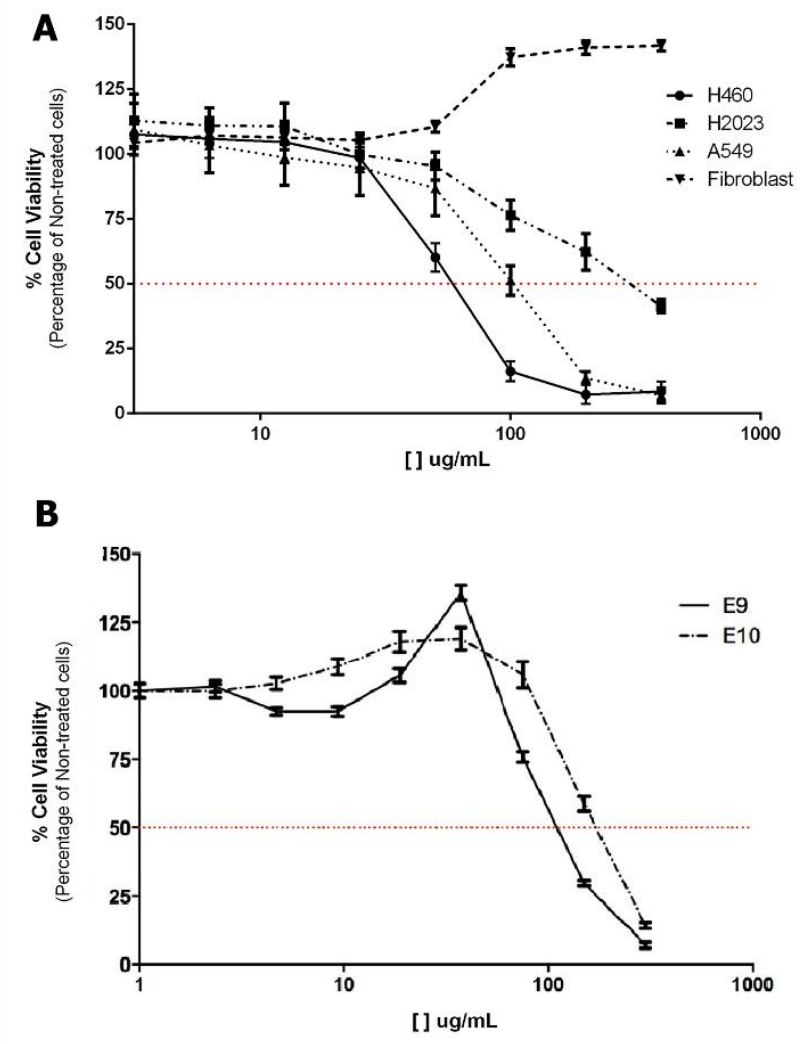

Figure 1. Cytotoxicity of LPE in human and murine lung cell lines. (A) LPE was cytotoxic for all human cancer cell lines. Normal fibroblasts were not affected by LPE at maximum concentration of $400 \mu \mathrm{g} / \mathrm{mL}$. (B) Mouse cell lines also presented a concentration-dependent effect being the cancer cell line (E9) more affected by LPE than the non-cancer cell line (E10). The tests were performed in six replicates and three experiments. Error bars indicate standard deviation. 
Table 2. $\mathrm{IC}_{50}$ of LPE extract in cancer and non-cancer cell lines

\begin{tabular}{cc}
\hline Cell lines & $\underline{\mathbf{I C}_{50} \underline{\mu \mathrm{g} / \mathrm{mL}}}$ \\
\hline A549 & 108.8 \\
H460 & 67.55 \\
H2023 & 353.4 \\
BJ & $>400$ \\
E9 & 157.2 \\
E10 & 274.8 \\
\hline
\end{tabular}

Next, we used a murine in vitro model to determine whether the cytotoxic effect of LPE is more specific to cancer cells than non-cancer cells. The E9-E10 mouse model presented one immortalized lung epithelial cell line (E10) and the sibling pair originated from spontaneous transformation (E9) [16]. E10 cells resemble type-II lung epithelial cell lines and E9 cell is a lung adenocarcinoma cell line. We performed the cytotoxic evaluation on both cell lines and found that LPE was almost twice as cytotoxic in cancer cells than in non-cancer cells (Table 2 and Fig. 1).

As already demonstrated, LPE induces cytotoxic effects on human and mouse lung cancer cell lines. Therefore, we investigated whether LPE arrested cancer cells in a specific phase of the cell cycle. Flow cytometry analysis of the cell cycle showed that the majority of cancer cells were arrested in the sub-G1 phase, indicating cell death after exposure to LPE. There was a significant difference in the number of cells in the sub-G1 and $S$ phases between control and treated cells, while there was no difference in the number of cells in G1 and G2/M (Fig. 2). The IC $\mathrm{I}_{50}$ of LPE in cancer cells induced sub-G1 cell cycle arrest, which occurred by apoptosis mediated by caspase- 3 activation as shown by the increased number of cancer cells with elevated caspase-3 activity (Mean \pm SD: LPE $17.43 \% \pm 1.59$; Control = $4.20 \% \pm 2.85 ; p=0.0014$; Fig. 3).

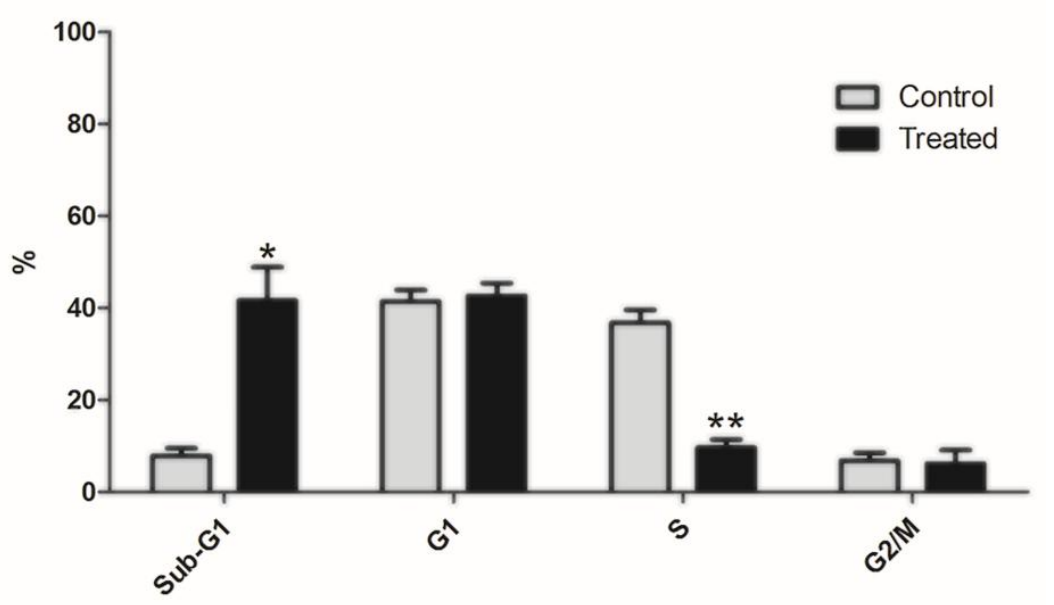

Figure. 2. Cell cycle analysis of cancer cells after exposure to $I_{C_{50}}$ of LPE. (A) Control. (B) Treated cells. (C) Non-treated H460 cells used as control and H460 cells after 72 hours with LPE. Note an increase on Sub-G1 population indicating cell death induced by the extract. ( $\left.{ }^{*} p \leq 0,01 ;{ }^{* *} p \leq 0,005\right)$. Tests were performed in triplicates. 


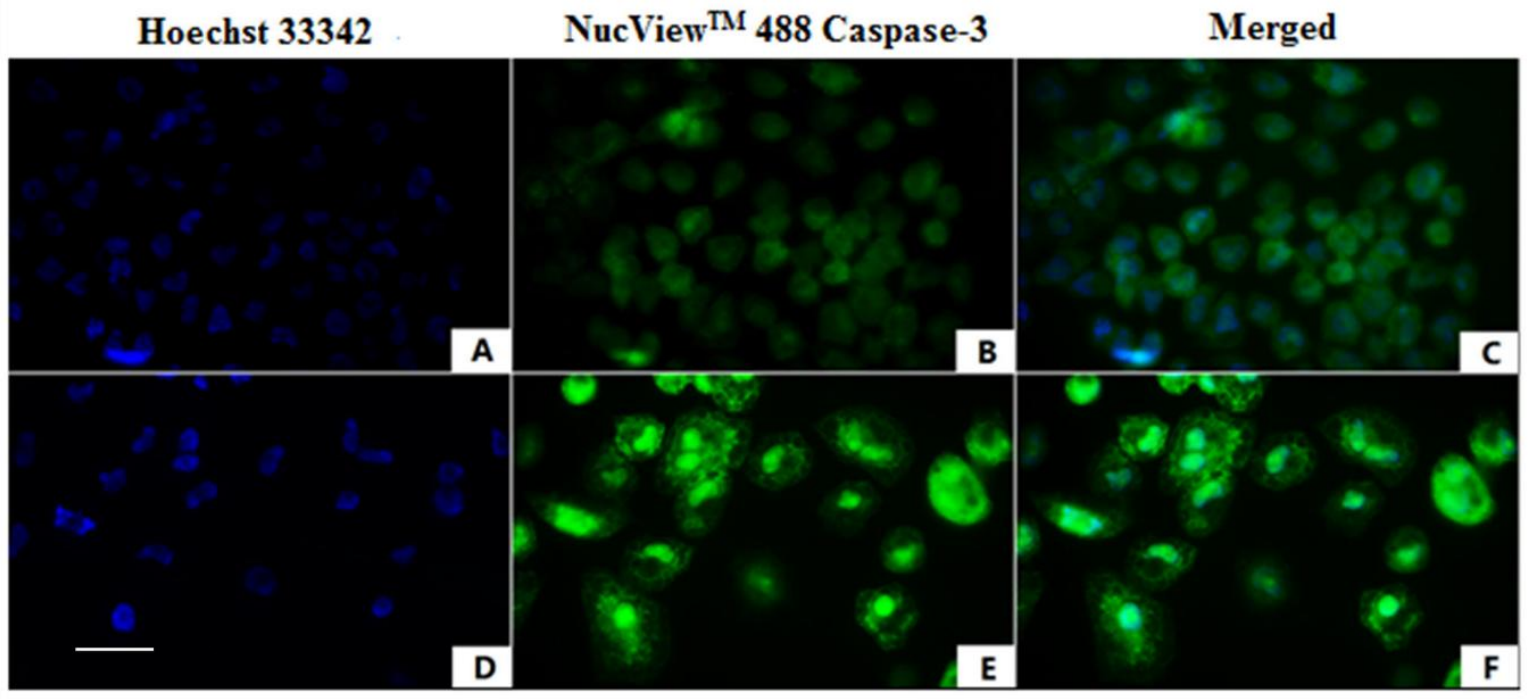

Figure 3. Caspase-3 activity in $\mathrm{H} 460$ cancer cells exposed to $I C_{50}$ of LPE. Hoechst was used to nuclear identification. (A, B, C) Control. (D, E, F) Treated cells. Magnification 200x. Scale bar: 100um.

The well-defined standard curve for tannic acid was used to estimate the total tannins. As shown on Table 3, the dried extract contained more than twice the tannin concentration found in powdered bark and inner bark, suggesting that aqueous ethanol is an effective solvent to concentrate these bioactive compounds from the initial plant.

Table 3. Quantification of total tannins mass of both crude ethanolic extract and the powdered bark and inner bark of $L$. pacari.

\begin{tabular}{cc}
\hline & $\mathrm{g} / \mathbf{1 0 0 \mathrm { g }}$ \\
\hline Powdered bark and inner bark & 20.89 \\
Ethanolic extract & 56.09 \\
\hline
\end{tabular}

Mass spectrum of the hydroethanolic extract showed three major peaks at ESI in ion positive mode (Fig. 4). The major peaks resulting from the chromatogram integration (UV $280 \mathrm{~nm}$ ) had a fragmentation pattern of procyanidins, whereas peaks 6 and 9 presented a peak ar $579 \mathrm{~m} / \mathrm{z}$ derived from a protonated $([\mathrm{M}+\mathrm{H}]+)$ dimer with a molecular mass of $578 \mathrm{~m} / \mathrm{z}$. The same pattern was observed with peaks 10 and 11 showing an $\mathrm{m} / \mathrm{z} 291([\mathrm{M}+\mathrm{H}]+)$, probably corresponding to $(+)$ catechin or/and (-) epicatechin monomers, while peaks 2 and 14 represented trimers at $\mathrm{m} / \mathrm{z} 867([\mathrm{M}+\mathrm{H}]+)$, containing fragments of $\mathrm{m} / \mathrm{z} 579([\mathrm{M}+\mathrm{H}]+)$. The remaining peaks could not be identified (Table 4). 


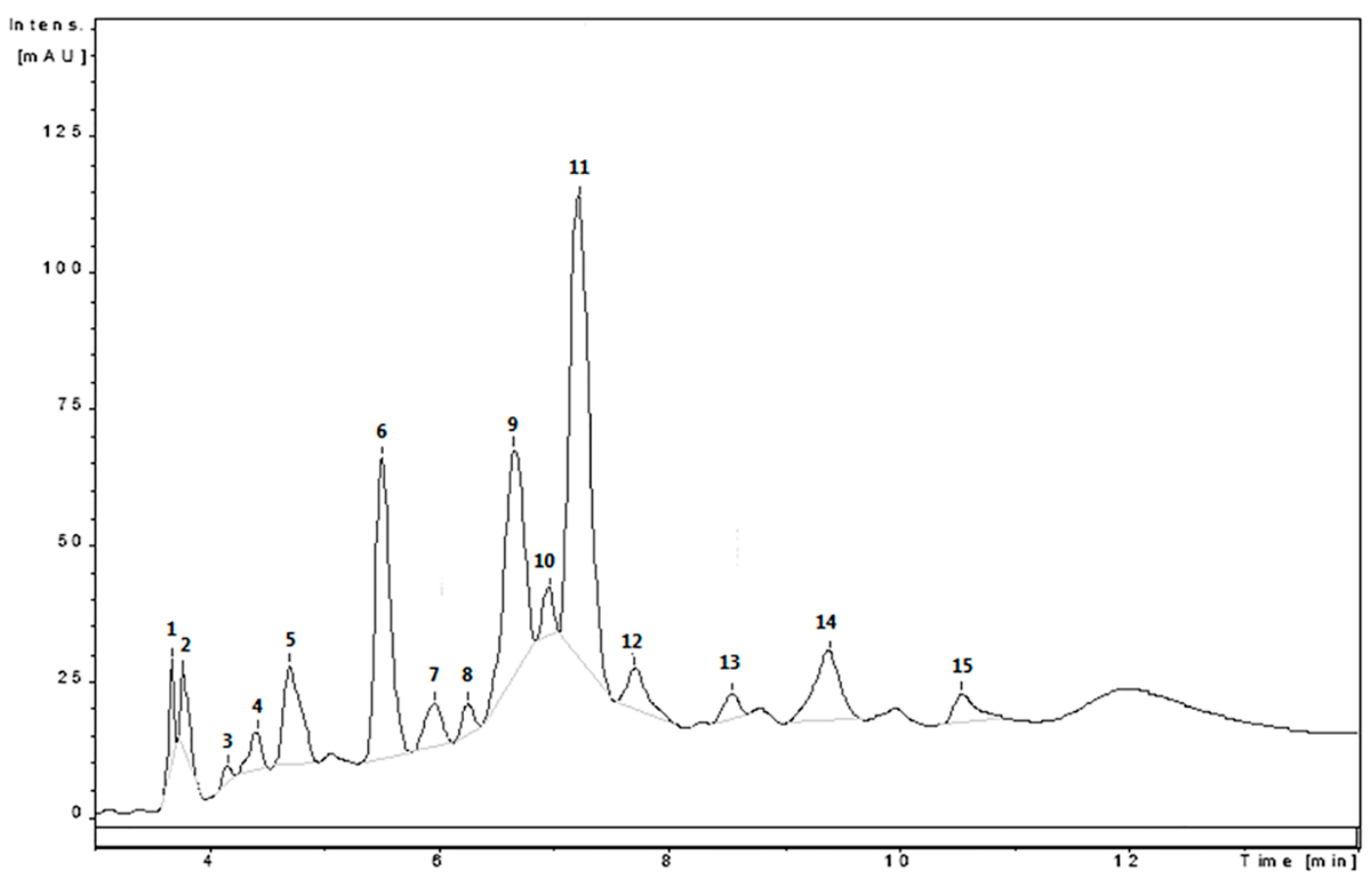

Figure 4. Integrated UV chromatogram at $280 \mathrm{~nm}$ of LPE. Three major peaks identified $(6,9,11)$ showing molecular mass equivalent to monomers and polymers of $(+)$ catechin and (-) epicatechin. Peaks 6 and 9 were identified as procyanidins $B, m / z 579\left[(\mathrm{M}+\mathrm{H})^{+}\right]$, corresponding to $33,26 \%$ of $\mathrm{LPE}$ total compounds.

Table 4. Peaks analysis at UV $280 \mathrm{~nm}$ of $L$. pacari ethanolic extract

\begin{tabular}{|c|c|c|c|}
\hline Peak & RT & $\%$ & $\mathbf{m} / \mathbf{z}[(\mathbf{M}+\mathrm{H})]+$ \\
\hline 1 & 3.68 & 2.00 & - \\
\hline 2 & 3.78 & 2.64 & $867(291,409,427,579)$ \\
\hline 3 & 4.15 & 0.57 & - \\
\hline 4 & 4.41 & 1.82 & - \\
\hline 5 & 4.69 & 6.42 & - \\
\hline$\underline{6}$ & $\underline{5.50}$ & $\underline{16.62^{*}}$ & $\underline{579(291,409,427)}$ \\
\hline 7 & 5.97 & 2.85 & - \\
\hline 8 & 6.25 & 1.31 & - \\
\hline$\underline{9}$ & $\underline{6.66}$ & $\underline{16.64^{*}}$ & $\underline{579(291,409,427)}$ \\
\hline 10 & 6.96 & 1.84 & $291(122,138,164,272)$ \\
\hline$\underline{11}$ & $\underline{7.22}$ & $\underline{33.63^{*}}$ & $\underline{291}$ \\
\hline 12 & 7.70 & 3.14 & - \\
\hline 13 & 8.55 & 1.39 & - \\
\hline 14 & 9.40 & 6.88 & $867(579)$ \\
\hline 15 & 10.56 & 2.25 & 579 \\
\hline
\end{tabular}

* Three major peaks corresponding to approximately $67 \%$ of LPE total compounds

The fragment from peak 6 (RT 5.50) at $\mathrm{m} / \mathrm{z} 579.22$ produced three fragments indicating the presence of type B procyanidins (epicatechin- $(4 \beta \rightarrow 8)$-epicatechin) in a MS/MS (m/z 246, m/z 291, m/z 407 and m/z 427) as described previously using the same 
procedure [17]. In addition we observed a fragment at $\mathrm{m} / \mathrm{z} 291([\mathrm{M}+\mathrm{H}]+)$ equivalent to epicatechin monomers that have a molecular mass of 290 (Fig. 5). In conclusion, the peaks described by ESI in positive ion mode (Table 4) are procyanidins at different levels of oligomerization.
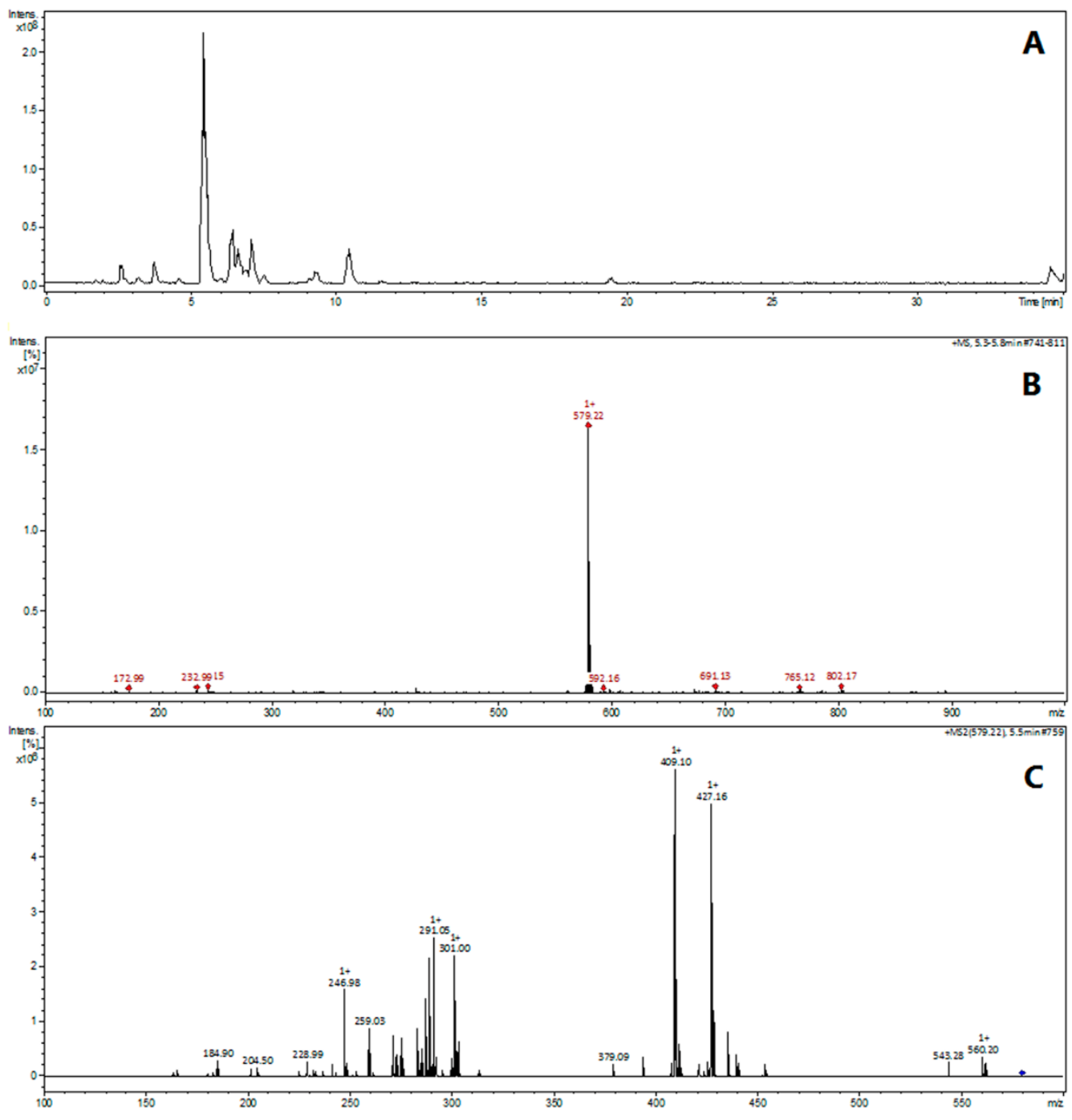

Figure 5. Mass spectra from positive ion mode. A-Major peaks detected; B-Peak 6 and C-fragmentation of peak $6 \mathrm{MS} / \mathrm{MS}$ for $\mathrm{m} / \mathrm{z} 579.22$ with characteristic fragments at the procyanidin $B$ (epicatechin-( $4 \beta \rightarrow 8)$-epicatechin).

\section{DISCUSSION}

Plants have been a great source of drugs that are effective for the treatment of many forms of cancer. In the past few years, a substantial number of Brazilian plants with interesting anti-cancer activity have been studied, including Casearia sy/vestris, Simarouba versicolor [18], and Paullinia cupana [7,19], demonstrating effects such as free-radical scavenging, enzyme inhibition, antiproliferativeness and anti-inflammation [20]. Here, we demonstrated that a Lafoensia pacari extract that is rich in procyanidins induces caspase-3-mediated apoptosis in human and murine cancer cells, illustrating its anti-neoplastic potential. This effect is more pronounced in cancer cells than non-tumorigenic cells in both species.

Lafoensia pacari appears to have therapeutic potential given its widespread use in traditional medicine, and has been the focus of increasing interest [12,21.22]. The L. pacari 
stem bark extract has already demonstrated anti-ulcer effects in an animal model of ethanol and indomethacin-induced gastric ulcers [22] and anti-inflammatory activity against carragenin-induced paw oedema in mouse [23]. Here we demonstrated that the mode of action of LPE on human cancer cells involves the induction of sub-G1 cell cycle arrest due to apoptotic cell death mediated by caspase-3 activation. This result is consistent with that of Marcondes and coworkers, who evaluated the effect of $L$. pacari stem bark methanolic extract in leukemic cell lines [21]. In their study, the authors reported that other compounds apart from elagic acid could be responsible for its cytotoxic effects.

Apoptosis is one mechanism of cell death that is induced mainly by natural and/or disease-induced factors involving a great machinery and cell cycle control [24]. Cancer cells generally acquire resistance to apoptosis, this being one of the hallmarks of cancer [25]. Apoptosis is traditionally thought to be induced by the extrinsic (death receptor) pathway or by the intrinsic (mitochondrial) pathway. However, there may be a possible connection between the two pathways, leading to a final execution pathway [26]. Caspase cleavage is one of the events that occur during apoptosis. The successive cleavage of these enzymes leads to subsequent cleavage and activation of caspase-3, resulting in apoptotic cell death by means of interactions between a wide range of cellular target proteins. Caspase- 3 is a critical effector of the apoptosis pathway with the ability to activate other caspases that promote cell death. Our results are similar to those of Wang and Lin (1999), who demonstrated that flavonoids can stimulate the activity of caspase-3, inducing apoptosis [27].

In the present study, the crude ethanolic extract and powdered and inner bark of $L$. pacari contained high levels of total tannins. These polyphenolic compounds are widely distributed in plants, food and beverages, occurring in approximately $30 \%$ of all plants [28]. The moderate intake of some types of tannins may be beneficial for human health, affecting the activity of metabolic enzymes, promoting immunomodulation and other beneficial functions [29]. According to their chemical structure, tannins are classified in two groups: hydrolysable and condensed tannins. The LC-ESI-MS analysis of LPE presented repeated peaks, the most significant ones representing the monomer and polymers of $(+)$-catechin and (-)-epicatechin, compounds known as proanthocyanidins. Molecules that consist solely of epicatechin units are also called procyanidins, and represent the most plentiful type of proanthocyanidins in plants. These condensed tannins are widely found in nuts, seeds, fruit and bark, and have been widely investigated not only for their potential therapeutic action, but also as a way to prevent several types of cancer [30]. The grape seed proanthocyanidin proved to be a potential chemopreventive agent, reducing cell proliferation, inducing apoptosis and cell cycle arrest and modulating the expression of several genes in tumor cells [31,32]. Likewise, epigallocatechin-3-gallate, a proanthocyanidin from green tea, induced apoptosis through caspase- 3 and 9 activation, leading to subsequent cell death [33].

The LC-MS in positive ion spectra at $280 \mathrm{~nm}$ revealed predominant peaks. Although the negative mode is known to be more efficient for the detection of procyanidins, the fragmentation patterns found in this study correspond to those described in grape and wine extract by Sun \& Muller in 2003 [17]. It was possible to identify peaks with a molecular mass equivalent to monomers and polymers of catechin and epicatechin. Two of the three major peaks, which together correspond to $1 / 3$ of the LPE total extract compounds, showed an $\mathrm{m} / \mathrm{z}$ $[(\mathrm{M}+\mathrm{H})+]$ of 579 , derived from protonated dimers with a molecular mass of 578 , characteristic of, more specifically, procyanidin B1 or epicatechin $(4 \beta \rightarrow 8)$ catechin, and procyanidin B2 or epicatechin- $(4 \beta \rightarrow 8)$ epicatechin [34]. Recent studies have demonstrated the biological effect of this small group of procyanidins, the procyanidins $B$ [35]. Considered to be two of the main procyanidins, procyanidin B1 and B2 have shown potential antioxidant and antineoplastic effects against tumor cells, but the molecular basis of such physiological modulations is still not fully understood [36]. Our results showed a high amount of procyanidins $B$ in the LPE extract, which could at least in part be responsible for the cancer cell cytotoxicity and caspase-3-induced apoptosis. Such effects have previously been 
studied by Tyagi and coworkers when evaluating the effects of synthetic B2G2 in prostate cancer, which achieved cytotoxicity due to modulation of transcriptional factors involved in cell survival and inflammatory cascades, such as the NF-kB, AP1 and Stat3 signaling pathways [37]. In addition, the activity of procyanidin B2 in azoxymethane (AOM)-induced colonic preneoplastic aberrant crypt foci (ACF) led to increased activity of caspase- 3 and subsequent apoptosis in cancer cells; furthermore, the number of macrophages and NK cells was significantly increased when compared to the control [38]. This data suggests that procyanidins have antineoplastic properties, increasing survival by directly altering tumor behavior.

\section{CONCLUSION}

This work describes the presence of procyanidins in LPE through LC-MS analysis, and the antineoplastic effect of Lafoensia pacari on human and murine lung cancer cells through sub-G1 cell cycle arrest due to apoptosis induced by caspase-3 activation. Future research efforts will concentrate on determining which procyanidin is responsible for this cytotoxic effect. In vivo preclinical studies will be necessary to evaluate potential adverse and antineoplastic effects of LPE.

Funding: This work was funded by FAPESP (2014/02493-7).

Conflicts of Interest: The authors declare no conflict of interest. The funders had no role in the design of the study; in the collection, analyses, or interpretation of data; in the writing of the manuscript, or in the decision to publish the results.

\section{REFERENCES}

1. Bullitta S, Piluzza G, and Viegi, L. Plant resources used for traditional ethnoveterinary phytotherapy in Sardinia (Italy). Genet. Resour. Crop Evol. 2007;54(7):1447-1464

2. Cragg GM, Newman DJ. Plants as a source of anti-cancer agents. J. Ethnopharmacol. 2005;100(1-2):72-9.

3. Elvin-Lewis, M. Should we be concerned about herbal remedies. J. Ethnopharmacol. $2001 ; 75(2-3): 141-164$.

4. Sriram, D., Yogeeswari, P., Thirumurugan, R., Bal, T.R., 2005. Camptothecin and its analogues: a review on their chemotherapeutic potential. Nat. Prod. Res. 19, 393-412. doi:10.1080/14786410412331299005

5. Wani M, Taylor H, Wall M, Coggon P, McPhail, A. Plant anti-tumor agents. VI. The isolation and structure of taxol, a novel anti-leukemic and anti-tumor agent from Taxus brevifolia. Am. Chem. Soc. 1971;93:2325-27.

6. Fukumasu H, da Silva TC, Avanzo JL, de Lima CE, Mackowiak II, Atroch A, Spinosa HS, Moreno FS, Dagli MLZ. Chemopreventive effects of Paullinia cupana Mart var. sorbilis, the guaraná, on mouse hepatocarcinogenesis. Cancer Lett. 2006;233(1):158-64.

7. Fukumasu H, Avanzo JL, Nagamine MK, Barbuto JA, Rao KV, Dagli MLZ. Paullinia cupana Mart var. sorbilis, guaraná, reduces cell proliferation and increases apoptosis of B16/F10 melanoma lung metastases in mice. Brazilian J. Med. Biol. Res. 2008;41(4):305-310.

8. Surh Y. Cancer Chemoprevention with dietary phytochemicals. Nature Reviews. 2003;3:768-780.

9. Filho VS, Yunes RA. Estrategies for obtaining pharmacologically active compounds from medicinal plants. Concepts about structural modification for improve the activity. Quim. Nova. 1998;21(14):99-105.

10. Mukherjee AK, Basu S, Sarkar N, Ghosh AC. Advances in cancer therapy with plant based natural products. Curr. Med. Chem.2001;8(12):1467-86.

11. Souza LKH, de Oliveira CMA, Ferri PH, Santos SC, de Oliveira Júnior JG, Miranda ATB et. al. Antifungal properties of Brazilian cerrado plants. Brazilian J. Microbiol. 2002;33(3):247-249.

12. Solon S, Lopes L, de Sousa PT, Schmeda-Hirschmann G. Free radical scavenging activity of Lafoensia pacari. J. Ethnopharmacol. 2000;72(1-2):173-8. 
13. Pott A, Pott V. Plantas do Pantanal. EMBRAPA-CPAP. Corumba. 1994 Accessed in October, 16th $2015 . \quad$ Available in: http://www.sidalc.net/cgi-bin/wxis.exe/?IsisScript=ACERVO.xis\&method=post\&formato=2\&cantidad $=1$ \&expresion $=\mathrm{mfn}=046692$.

14. Ferlay J, Soerjomataram I, Dikshit R, Eser S, Mathers C, Rebelo M, Parkin DM, Forman D, Bray F. Cancer incidence and mortality worldwide: Sources, methods and major patterns in GLOBOCAN 2012. Int J Cancer. 2015; 136(5):359-86.

15. Hagerman AE, Butler LG. Protein precipitation method for the quantitative determination of tannins. J. Agric. Food Chem. 1978;26(4):809-812.

16. Malkinson AM, Dwyer-Nield LD, Rice PL, Dinsdale D. Mouse lung epithelial cell lines--tools for the study of differentiation and the neoplastic phenotype. Toxicology. 1997;123(1-2):53-100.

17. Sun W, Miller JM. Tandem mass spectrometry of the B-type procyanidins in wine and B-type dehydrodicatechins in an autoxidation mixture of (+)-catechin and (-)-epicatechin. J. Mass Spectrom. 2003;38(4):438-446.

18. Mesquita ML, Paula JE, Pessoa C, Moraes MO, Costa-Lotufo LV, Grougnet R et. al. Cytotoxic activity of Brazilian Cerrado plants used in traditional medicine against cancer cell lines. $J$. Ethnopharmacol. 2009;123(3):439-45.

19. Fukumasu H, Latorre AO, Bracci N, Górniak SL, Dagli MLZ. Fitoterápicos e potenciais interações medicamentosas na terapia do câncer. Rev. Bras. Toxicol. 2008;21(2):49-59.

20. Galdino PM, Nascimento MVM, Sampaio BL, Ferreira RN, Paula JR, Costa EA. Antidepressant-like effect of Lafoensia pacari A. St.-Hil. ethanolic extract and fractions in mice. J. Ethnopharmacol. 2009;124(3):581-5.

21. Marcondes DBS, Reichert CL, Andrade LF, Santos CAM, Weffort-Santos AM. Cytotoxicity and apoptogenic effects of Lafoensia pacari. J. Ethnopharmacol. 2014;(157):243-250.

22. Tamashiro FP, Olaitan B, Almeida DAT, Lima J, Marson-Ascêncio P, Ascêncio S et. al. Evaluation of antiulcer activity and mechanism of action of methanol stem bark extract of Lafoensia pacari A. St.-Hil. J. Ethnopharmacol. 2012;144:497-505.

23. Albuquerque DA. Efeito do extrato etanólico de Lafoensia pacari sobre a peritonite aguda em camundongos. Anais 3a Reuniao especial da SBPC "Ecossistemas Costeiros-do conhecimento a gestao" 1996.

24. Elmore S. Apoptosis: a review of programmed cell death. Toxicol. Pathol. 2007;35(4):495-516.

25. Hanahan D, Weinberg RA. The hallmarks of cancer. Cell. 2000;100:57-70.

26. Igney $\mathrm{FH}$, Krammer $\mathrm{PH}$. Death and anti-death: tumour resistance to apoptosis. Nat. Rev. Cancer. 2002;2(4):277-288.

27. Wang I, Lin J. Induction of Apoptosis by Apigenin and Related Flavonoids Through Cytochrome c Release and Activation of Caspase- 9 and Caspase-3 in Leukaemia HL-60 Cells. Eur. J. Cancer. 1999;35(10):1517-1525.

28. Pansera MR, Santos ACA, Paese K, Wasum R, Rossato M, Rota LD et. al. Análise de taninos totais em plantas aromáticas e medicinais cultivadas no Nordeste do Rio Grande do Sul. Rev. Bras. Farmacogn. 2003;13(1):17-22.

29. Chung K, Wong TY, Wei C, Huang Y, Lin Y. Tannins and Human Health: a review. Crit. Rev. Food Sci. Nutr. 2013;38(6):37-41.

30. Nandakumar V, Singh T, Katiyar SK. Multi-targeted prevention and therapy of cancer by proanthocyanidins. Cancer Lett. 2008;269(2):378-87.

31. Mantena SK, Baliga MS, Katiyar SK. Grape seed proanthocyanidins induce apoptosis and inhibit metastasis of highly metastatic breast carcinoma cells. Carcinogenesis. 2006;27(8):1682-91.

32. Meeran SM, Katiyar SK. Grape seed proanthocyanidins promote apoptosis in human epidermoid carcinoma A431 cells through alterations in Cdki-Cdk-cyclin cascade, and caspase- 3 activation via loss of mitochondrial membrane potential. Exp. Dermatol. 2007;16(5):405-15.

33. Shankar S, Suthakar G, Srivastava RK. Epigallocatechin-3-gallate inhibits cell cycle and induces apoptosis in pancreatic câncer. Front. Biosci. 2007;12:5039-5051.

34. De Bruyne T, Pieters L, Witvrouw M, De Clercq E, Vanden Berghe D, Vlietinck AJ. Biological evaluation of proanthocyanidin dimers and related polyphenols. J. Nat. Prod. 1999;62(7):954-958. 
35. Rodríguez-Ramiro I, Ramos S, Bravo L, Goya L, Martín MA. Procyanidin B2 induces Nrf2 translocation and glutathione S-transferase P1 expression via ERKs and p38-MAPK pathways and protect human colonic cells against oxidative stress. Eur. J. Nutr. 2012;51(7):881-92.

36. Tyagi A, Agarwal R, Agarwal C. Grape seed extract inhibits EGF-induced and constitutively active mitogenic signaling but activates JNK in human prostate carcinoma DU145 cells: possible role in antiproliferation and apoptosis. Oncogene. 2003;22(9):1302-16.

37. Tyagi A, Raina K, Shrestha SP, Miller B, Thompson JA, Wempe MF et. al. Procyanidin B2 3,3(")-di-O-gallate, a biologically active constituent of grape seed extract, induces apoptosis in human prostate cancer cells via targeting NF-KB, Stat3, and AP1 transcription factors. Nutr. Cancer. 2014;66(4):736-46.

38. Nomoto H, ligo M, Hamada H, Kojima S, Tsuda H. Chemoprevention of Colorectal Cancer by Grape Seed Proanthocyanidin Is Accompanied by a Decrease in Proliferation and Increase in Apoptosis. Nutr. Cancer. 2004;49(1):81-88.

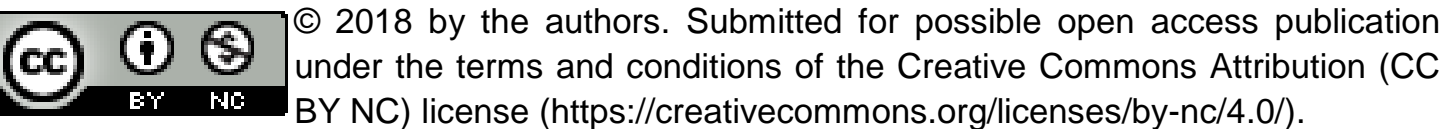

